\title{
ETIKA KONSUMSI DALAM PERSPEKTIF EKONOMI ISLAM
}

\author{
Andi Bahri S. \\ STAIN Parepare Jl. Amal Bhakti No. 8 Soreang Kota Parepare \\ E-mail: laulaka@gmail.com
}

\begin{abstract}
Abstrak. Tulisan ini membahas bagaimana perilaku konsumsi di masyarakat? bagaimana anjuran Islam dalam berkonsumsi? dan bagaimana semestinya perilaku konsumsi menurut pandangan ekonomi Islam? Berdasarkan hasil analisis, diperoleh kesimpulan sebagai berikut: 1) Perilaku konsumsi semestinya memperhatikan aspek-aspek yang tergolong kebutuhan primer (darūriyyah) kemudian sekunder (hājjiyāt) dan trisier (tahsinniyyah) sesuai dengan semangat al-maqāșid al-syarīah. Dalam pandangan Islam, perilaku konsumsi harus menghindari perilaku isrāf dan tabżīr dalam menggunakan pendapatan untuk memenuhi kebutuhan hidup. Dalam hal konsumsi pangan, umat Islam harus senantiasa menjaga unsur ke-halal-an dan ke-tayyiban-an. Perilaku konsumsi dalam ekonomi Islam bertujuan agar tercapai aspek materil dan aspek spiritual dalam konsumsi, kedua aspek tersebut akan tercapai dengan memaksimumkan nilai guna dari tiap barang yang dikonsumsi.
\end{abstract}

Abstract. This paper deals with consumption behavior in society; how to consume as recommended by Islam; and how should consumption behavior in the view of Islamic economics. Based on the results of the analysis, we concluded as follows: 1) Consumption behavior should pay attention to the aspects of the categories of needs asprimary needs, secondary needs and tertiary needs in accordance with the spirit of al-maqāșdalsyarīah. In the view of Islam, consumption behavior should avoid isrāf and tabżīr behavior in using their income to meet their life needs. In the aspect of comsuming any kind of food, the Muslims should always comsume the halal and the toyyib food. Consumption behavior in Islamic economics aims at achieving both the aspect of material and the aspect of spriruality, these two aspects will be achieved by maximizing the value of the use of each item in consumption.

Kata kunci: Perilaku konsumsi, kebutuhan, keingingan, ekonomi islam 


\section{PENDAHULUAN}

Indonesia sebagai salah satu Negara dengan penduduk terbanyak di Dunia khususnya di kawasan ASEAN sekaligus sebagai Negara dengan penduduk mayoritas muslim. Sebagai Negara dengan penduduk terbanyak di Dunia hal ini akan menjadikan Indonesia sebagai pasar potensial untuk masuknya barang, jasa dan tenaga kerja terampil dari berbagai Negara lainnya di ASEAN.

Sebagai anggota ASEAN tentunya Indonesia mempunyai peran yang sangat strategis dalam implementasi Masyarakat Ekonomi ASEAN yang dikenal dengan istilah MEA yang akan dimulai di tahun 2015, terbentuknya MEA merupakan wujud dari keingingan negara-negara ASEAN untuk menjadikan ASEAN sebagai kawasan perekonomian yang solid dan diperhitungkan dalam perekonomian Internasional, dengan wujud adanya aliran bebas barang dan jasa, tenaga kerja terlatih (skilled labor), serta aliran investasi yang lebih bebas. ${ }^{1}$

Dengan implementasi tersebut, Indonesia sebagai anggota ASEAN akan sangat berpotensi untuk dibanjiri barang-barang konsumsi. Membanjirnya barang-barang tersebut memang memiliki nilai positif bagi konsumen, dalam hal ini akan semakin banyaknya alternatif pilihan barang dan jasa yang dapat dikonsumsi. Namun demikian, di lain sisi jika hal ini tidak disikapi secara bijaksana justru akan menumbuh-suburkan budaya konsumtif pada masyarakat. Yang pada banyak kasus, perilaku konsumtif ini tidak didasarkan lagi pada teori kebutuhan (need), tetapi didorong oleh hasrat (desire) dan keinginan (want).

Pergeseran perilaku konsumsi yang tidak lagi untuk memenuhi kebutuhan tetapi didasarkan pada motivasi untuk mendapatkan tantangan, suatu sensasi, kegembiraan, sosialisasi,

${ }^{1}$ Margaretha Ardhanari, Memelihara Budaya: Perspektif Masyarakat Konsumen dan Perilakunya, makalah orasi ilmiah dalam rangka Dies Natalis Universitas Katolik Widya Mandala Surabaya ke-53 tahun 2014, h. 2. 
menghilangkan stress, memberikan pengetahuan baru tentang perkembangan trend baru dan model baru serta untuk menemukan barang yang baik dan bernilai bagi diri masyarakat. Maka tidak mengherankan ketika melihat grafik investasi dan saving selalu bergerak turun dari waktu ke waktu. Wabah budaya konsumtif sangat mencemaskan jika tidak diantisipasi. Hal yang berbahaya adalah ketergantungan pada barang-barang impor, dimana hal ini akan mematikan pasar produk lokal. Sehingga budaya konsumtif masyarakat akan menjadi "undangan" terbuka bagi kapitalisme global untuk memengaruhi pola pikir, gaya hidup (life style) dan selera untuk menyesuaikan dengan nilai yang melekat pada barang yang mereka hasilkan. Akhirnya masyarakat akan terdorong untuk merubah gaya hidup dengan cepat, mengikuti trend tingkat konsumsi, mode, perilaku sosial serta hasrat untuk terus mengikuti produk-produk baru yang diproduksi secara up todate. ${ }^{2}$

Kondisi ini seakan-akan menggugah "ketentraman" seluruh lapisan masyarakat baik tua-muda, kaya ataupun miskin, walaupun kondisi perekonomian yang tidak menentu, semua terjangkiti "virus budaya konsumtif". Iklan menjadi salah satu alat yang ampuh untuk memasukkan virus ini, ironisnya ada yang menyadarinya tetapi banyak pula yang tidak.

Di sudut lain, Indonesia dipandang sebagai negara dengan penduduk mayoritas muslim, tentunya menjadi pontensi pasar tersendiri bagi masuknya produk-produk halal dari berbagai negara yang nota bene mempunyai tempat tersendiri di kalangan kunsumen muslim sebagai subyek yang semestinya memperhatikan unsur ke-halāl-an dan ke-țyyiban-an dalam konsumsi, hal ini banyak dikuatkan dengan nash-nash dari Alquran dan hadis sebagai pedoman hidup bagi setiap muslim di dunia.

${ }^{2}$ Ibid., h. 3. 


\section{KAJIAN TEORETIS: PERILAKU KONSUMSI}

Perilaku konsumsi yang dikenal dalam istilah bahasa Inggris consumtion behavior makin penting keberadaannya setelah ekonom Inggris John Mynar Lord Kynes (1883-1946) memperkenalkan teorinya yang dikenal dengan istilah Low of Consumtion (Hukum Konsumsi) yang belakangan mengilhami para penulis ilmu ekonomi mempopulerkan istilah perilaku konsumen dalam tulisan mereka.

Perilaku konsumsi sejatinya teori yang dikembangkan dari muara pemahaman akan rasionalisme ekonomi dan utilitarianisme kapitalis. ${ }^{3}$ Rasionalisme ekonomi menafsirkan perilaku manusia sebagai sesuatu yang dilandasi dengan perhitungan cermat akan arah pandangan kedepan dan persiapan akan keberhasilan ekonomi (materil), sedangkan utilitarianisme ditafsirkan sebagai sesuatu yang berlandaskan pada nilai dan sikap moral.

Sedangkan menurut Engel perilaku konsumsi adalah tindakan yang terlibat langsung dalam mendapatkan, mengonsumsi dan menghabiskan produk dan jasa, termasuk proses keputusan yang mendahului dan mengikuti tindakan itu. Dan menurut Loudon dan Bitta, perilaku konsumsi adalah suatu proses pengambilan keputusan yang mensyaratkan perilaku individu untuk mengevaluasi, memperoleh, menggunakan dan mengatur barang dan jasa. Adapun menurut Kotler dan Amstrong, perilaku konsumsi adalah perilaku individu ataupun rumah tangga dalam bentuk pembelian barang dan jasa untuk konsumsi personal.

Dari beberapa pengertian tersebut dapat dirangkum menjadi komponen-komponen seperti berikut: 1. Perilaku konsumsi menyoroti perilaku individu dan rumah tangga, 2.

${ }^{3}$ M. Arif Mufraini, Akuntansi dan Manajemen Zakat-Mengomunikasikan Kesadaran dan Membangun Jaringan (Cet. ke-1 ; Jakarta: Kencana Prenada Media Group, 2006), h. 211. 
Perilaku konsumsi menyangkut suatu proses keputusan sebelum pembelian serta tindakan dalam memperoleh, memakai dan menghabiskan suatu produk; dan 3. Perilaku konsumsi meliputi perilaku yang dapat diamati seperti jumlah yang dibeli, kapan, dengan siapa dan oleh siapa serta bagaimana barang yang sudah dikonsumsi.

Dengan demikian perilaku konsumsi merupakan perilaku keseharian setiap individu atau rumah tangga dalam menggunakan barang dan jasa guna memenuhi kebutuhan diri atau keluarga. Hal ini dapat berbentuk penggunaan satu jenis barang dan jasa untuk memenuhi khusus kebutuhan lahiriah dan dapat bersifat memenuhi khusus kebutuhan batiniah dan dapat pula bersifat memenuhi kebutuhan sekaligus, baik lahiriah maupun batiniah. Perilaku konsumsi dapat berbentuk penggunaan berbagai jenis barang dan jasa seperti sandang, pangan, alat komunikasi dan lain-lain yang bermuara pada pemenuhan kebutuhan hidup sebagai makhluk biologis.

Perilaku konsumsi dalam waktu yang lama lebih dikenal dalam dua macam yaitu perilaku konsumsi rumah tangga individu dan perilaku konsumsi rumah tangga perusahaan. Dikenalnya dua macam perilaku konsumsi tersebut karena keduanya merupakan subyek permintaan. Akan tetapi menurut Sulistyo, perilaku konsumsi rumah tangga individu menjadi lebih tepat disebut perilaku konsumsi saja dan perilaku konsumsi rumah tangga perusahaan disebut investasi. ${ }^{4}$ Hal itu terjadi sebab pada kenyataannya, isi permintaan yang datang dari rumah tangga individu adalah permintaan akan barang dan jasa untuk memenuhi kebutuhan hidup; dengan kata lain, barang dan jasa yang diminta oleh satu individu atau sebuah rumah tangga dimaksudkan untuk dikonsumsi. Sedangkan permintaan yang datang dari rumah tangga perusahaan pada umumnya ditujukan

${ }^{4}$ Sulistyo, Pengantar Ekonomi Makro (Cet. ke-3; Jakarta: Karunika Universitas Terbuka, 1986, h. 124. 
untuk membeli barang dan jasa modal yang diperlukan dalam proses produksi, karenanya permintaan akan barang dan jasa modal adalah bersifat investasi.

Islam sebagai pedoman hidup tidak menonjolkan standar atau sifat kepuasan dari sebuah perilaku konsumsi sebagaimana yang dianut dalam ilmu ekonomi konvensional seperti utilitas dan kepuasan marginal, melainkan lebih menonjolkan aspek normatif. Kepuasan dari sebuah perilaku konsumsi menurut Islam harus berlandaskan pada tuntunan ajaran Islam itu sendiri. Dalam hal ini Muhammad Nejatullah Siddiqi mengatakan, konsumen harus puas akan perilaku konsumsinya dengan mengikuti normanorma Islam. Konsumen muslim seharusnya tidak mengikuti gaya konsumsi kaum xanthous (orang-orang berkulit kekuningkuningan dan berambut kecoklat-coklatan) yang berkarakteristik menuruti hawa nafsu. ${ }^{5}$

Hal ini diperkuat dengan prinsip dasar dari perilaku konsumsi menurut M. Arif Mufraini (211) adalah seperti yang dikonfirmasikan Q.S. al-Baqarah (2): $168 .^{6}$

Hai sekalian manusia, makanlah yang halal lagi baik dari apa yang terdapat di bumi, dan janganlah kamu mengikuti langkah-langkah syaitan; Karena Sesungguhnya syaitan itu adalah musuh yang nyata bagimu.

Selain ayat tersebut, beberapa ayat lain menggariskan prinsip-prinsip pokok perilaku konsumsi, seperti ayat pada Q.S. al-Maidah (5): 88.

Dan makanlah makanan yang halal lagi baik dari apa yang Allah Telah rezekikan kepadamu, dan bertakwalah kepada Allah yang kamu beriman kepada-Nya.

Lebih tegas lagi, Yusuf Qardhawi menguraikan beberapa prinsip perilaku konsumsi dalam Islam sebagai berikut: ${ }^{7}$

${ }^{5}$ Muhammad Nejatullah Siddiqi, The Economic Enterprise, diterjemah oleh Anas Sidik, Kegiatan Ekonomi dalam Islam (Cet. ke-2; Jakarta: Bumi Aksara, 1996), h. 95.

${ }^{6}$ M. Arif Mufraini, Akuntansi..., h. 211. 
- Dasar pemikiran pola konsumsi dalam Islam adalah hendak mengurangi kelebihan keinginan biologis yang tumbuh dari faktor-faktor psikis buatan dengan maksud membebaskan energi manusia untuk tujuan-tujuan spiritual.

- Anjuran-anjuran Islam mengenai perilaku konsumsi dituntun oleh prinsip keadilan, prinsip kebersihan, prinsip kesederhanaan, prinsip kemurahan hati dan prinsip moralitas.

- Pada umumnya kebutuhan-kebutuhan manusia digolongkan ke dalam tiga hal, yaitu (a) barang-barang keperluan pokok, (b) barang-barang keperluan kesenangan dan (c) barang-barang keperluan kemewahan. Dalam tiga pengelompokan ini, Islam menggariskan prinsip menurut urutan prioritas kebutuhan yang dikenal dalam al-maqāșid al-syarīah dengan istilah darūriyyah, häjjiyah dan tahsiñiyyah. ${ }^{8}$

- Kunci untuk memahami perilaku konsumsi dalam Islam tidak cukup dengan hanya mengetahui hal-hal terlarang, tetapi sekaligus harus dengan menyadari konsep dinamik tentang sikap moderat dalam pola konsumsi yang dituntun oleh sikap yang mementingkan bersama konsumen muslim yang lain.

Dari hal-hal yang diuraikan diatas dapat dijelaskan bahwa prinsip perilaku konsumsi yang dapat memberikan kepuasan kepada konsumen menurut Islam adalah barang-barang yang dikonsumsi haruslah halal dan suci menurut syariat. Dalam hal perilaku atau gaya harus pula dalam batas wajar dalam arti tidak berlebih-lebihan (isyrāf) atau boros (tabżìr) meskipun seorang konsumen tergolong hidup kaya atau mampu.

Sedangkan prinsip perilaku konsumsi secara konvensional menurut Winardi, terpatok pada istilah kepuasan (utilitas). Istilah

${ }^{7} Y u s u f$ Qardhawi, Dawr al-Qiyam wa al-Akhlāq fí al-Iqtișad al-Islāmī, diterjemah oleh Zainal Arifin dan Dahlia Husim, Norma dan Etika Ekonomi Islam, (Cet. ke-4; Jakarta: Gema Insani Press, 1422 H./2001 M.), h. 352.

${ }^{8} \mathrm{Abu}$ Ishaq al-Syatibi, al-Muwāfaqāt Fī Ușūl al-Syarīah, Juz IV (Beirut: Dār al-Kutub al-'Ilmiyyah, t.th.), h. 7. 
kepuasan dimaksudkan sebagai kemampuan untuk memenuhi suatu kebutuhan. Kemampuan tersebut meliputi (1) kemampuan akan suatu benda material atau jasa untuk memenuhi kebutuhan manusia dan (2) kebutuhan yang berhubungan dengan istilah public policy. Istilah ini kemudian melahirkan istilah-istilah kepuasan tempat (utility of place), kepuasan waktu (utility of time) dan kepuasan kepemilikan (utility of possession). Kepuasan tempat, ialah kepuasan yang timbul karena fakta suatu benda atau jasa, tepat pada tempatnya untuk digunakan. kepuasan waktu, ialah kepuasan yang timbul karena fakta suatu benda atau jasa tersedia pada waktu dibutuhkan, sedangkan kepuasan kepemilikan, ialah kepuasan yang timbul karena fakta, suatu benda atau jasa yang ada, dimiliki oleh orang yang akan menggunakannya. ${ }^{9}$

Richard. G. Lipsey, Peter O. Steiner dan Donglas D. Purvis menulis - sebagaimana yang dikutip Winardi -bahwa yang dimaksud dengan utilitas ialah kepuasan yang diperoleh seseorang dari mengkonsumsi komoditi. Karena itu Richard G. Lipsey dan kawan-kawan, mengartikan utilitas selain bermakna kegunaan atau faedah, juga bermakna kepuasan. ${ }^{10}$ Dominick Salvatore memberi contoh dari utilitas dengan arti kepuasan seperti Individu yang meminta suatu komoditi tertentu, karena kepuasan yang diperoleh dari mengkonsumsi komoditi tertentu tersebut. ${ }^{11}$ Jadi istilah kepuasan perilaku konsumsi bermakna suatu kepuasan yang diperoleh seseorang atau sebuah rumah tangga melalui penggunaan akhir barang-barang dan jasa-jasa konsumsi dari berbagai komoditi.

\footnotetext{
${ }^{9}$ Winardi, Manajemen Perilaku Organisasi (Cet. ke-1; Bandung: Mandar Maju, 2003), h. 496.

${ }^{10}$ Richard. G. Lipsey, Steiner, O. Peter dan Purvis D. Douglas, Economics, diterjemah oleh Jaka Wasana dan Kirbandoko dengan judul, Pengantar Mikroekonomi, Jilid I (Edisi VIII; Jakarta: Erlangga, 1987), h. 135.

${ }^{11}$ Dominick Salvatore, Theory and Problems of Microeconomics, diterjemah oleh Rudy Sitompul, Teori Mikroekonomi (Cet. ke-3; Jakarta: Erlangga, 1995), h. 67.
} 
Beriringan dengan utilitas muncul pula kepuasan yang bersifat marginal, yang kemudian dipopulerkan oleh ilmuwan ekonomi dengan istilah kepuasan marginal dengan rumusan pengertian sebagai perubahan kepuasan yang dihasilkan dengan mengkonsumsi lebih banyak atau lebih sedikit komoditi.

Dalam konteks seperti ini, bahwa semakin tinggi tingkat pendapatan, akan semakin tinggi pula tingkat konsumsi, yang berarti akan tercapai kepuasan dalam perilaku konsumsi. Walau demikian sangat memungkinkan selalu terjaga kepuasan marginal atau kepuasan ekstra, baik dalam arti lebih maupun dalam arti kurang. Selain itu, dalam ikhtiar mencapai kepuasan total atau maksimal, haruslah ditopang oleh tindakan yang membelanjakan atas aneka komoditi atau barang dan jasa konsumsi secara seimbang.

Pada dasarnya perilaku konsumsi seseorang atau sebuah rumah tangga, menurut Salvatore adalah selalu berpijak atau berorientasi pada prinsip atau nilai kepuasan. ${ }^{12}$ Di samping itu kecermatan dan ketepatan membelanjakan pendapatan dalam membeli barang-barang dan jasa-jasa konsumsi untuk dapat mencapai kepuasan sangat diperlukan, meski kepuasan itu sendiri tidak mempunyai standar pengukuran yang pasti. Kepuasan itu sudah pasti pula tidak mempunyai titik persamaan antara satu individu dengan individu lainnya atau sebuah rumah tangga dengan rumah tangga lainnya. Utilitas itu bersifat sangat subyektif yakni tergantung pada masing-masing individu atau rumah tangga yang menjalaninya. Namun yang jelas secara konvensional, bahwa salah satu karakter utama dari perilaku konsumsi seseorang atau sebuah rumah tangga adalah kepuasan, baik dalam arti maksimun maupun dalam arti minimum.

\footnotetext{
${ }^{12}$ Ibid., h. 67.
} 


\section{PERILAKU KONSUMSI DI MASYARAKAT}

\section{Motif Perilaku Konsumsi Masyarakat}

Perilaku konsumsi seseorang dipengaruhi oleh latar belakang yang sangat kompleks. Latar belakang itu menurut Arif Mufraini antara lain, tingkat pengetahuan, wawasan, lingkungan sosial budaya, kemampuan ekonomi dan kepribadian (psikologis). Karena itu, antara seorang individu dengan individu lainnya akan berbeda sifat dan perilaku konsumsinya. Orang yang berpengetahuan dan berwawasan luas akan berbeda motif perilaku konsumsinya dengan orang yang berpengetahuan dan berwawasan sempit. Orang yang hidup di tengah-tengah lingkungan dan budaya yang maju akan berbeda motif perilaku konsumsinya dengan orang yang hidup ditengah-tengah lingkungan dan budaya terbelakang. Orang yang memiliki kehidupan ekonomi yang kuat akan berbeda motif perilaku konsumsinya dengan orang yang memiliki kehidupan ekonomi yang lemah. Orang yang memiliki kepribadian keagamaan yang baik akan berbeda motif perilaku konsumsinya dengan orang yang memiliki kepribadian keagamaan yang buruk; dan seterusnya. $^{13}$

Dalam perspektif agama Islam misalnya, bahwa motif perilaku konsumsi orang muslim, teristimewa yang memiliki pengetahuan dan wawasan agama serta keimanan yang baik adalah bermotifkan tuntunan perintah agama. Mengingat agama Islam memerintahkan makan, minum, berpakaian, bersilaturahim dan lain-lain agar tidak terjadi kerusakan diri, hal ini ditegaskan dalam Q.S. al-A'raaf (7): 31-32.

Hai anak Adam, pakailah pakaianmu yang indah di setiap (memasuki) mesjid, makan dan minumlah, dan janganlah berlebih-lebihan. Sesungguhnya Allah tidak menyukai orang-orang yang berlebihlebihan. Katakanlah: "Siapakah yang mengharamkan perhiasan dari Allah yang telah dikeluarkan-Nya untuk hamba-hamba-Nya dan (siapa pulakah yang mengharamkan) rezki yang baik?" Katakanlah:

${ }^{13}$ M. Arif Mufraini, Akuntansi..., h. 213. 
"Semuanya itu (disediakan) bagi orang-orang yang beriman dalam kehidupan dunia, khusus (untuk mereka saja) di hari kiamat." Demikianlah kami menjelaskan ayat-ayat itu bagi orang-orang yang mengetahui.

Dalam perspektif ilmu kesehatan misalnya, sudah pasti dapat dikatakan bahwa motif perilaku konsumsi seseorang adalah bagaimana senantiasa memiliki kesehatan yang prima. Demikian pula dalam perspektif adat dan budaya, bahwa motif perilaku konsumsi seseorang adalah di samping untuk memelihara kesehatan dan mungkin menjalankan perintah agama, sekaligus juga untuk mempertunjukkan dan memelihara khazanah kearifan lokalnya.

Dalam ilmu ekonomi konvensional, menurut Sulistyo disebutkan, bahwa perilaku konsumsi seseorang dipengaruhi oleh faktor internal di dalam diri manusia dan faktor eksternal dari luar diri manusia. Keynes mengemukakan, perilaku konsumsi didorong motif yang berasal dari dalam diri manusia itu sendiri yang bersifat subyektif, yaitu keinginan untuk memenuhi kebutuhan hidupnya. Orang meminta barang dan jasa karena barang dan jasa dapat memenuhi kebutuhan hidupnya yang bersifat material. Tetapi di lain pihak perilaku konsumsi seseorang dapat diimbas (include) dari luar melalui iklan-iklan yang gencar dipasang di berbagai media, hal ini dapat memengaruhi keputusan seseorang pada era modern untuk berkonsumsi. Banyak orang membeli barang dan jasa hanya karena tertarik oleh iklan dan sama sekali tidak ada kaitan dengan usaha pemenuhan kebutuhan hidupnya. Karena itu kata Sulistyo, pengaruh dari luar itu bersifat obyektif, sebab dapat memengaruhi perilaku konsumsi siapa pun juga. Kedua motif (subyektif dan obyektif) tersebut menggambarkan, perilaku konsumsi seseorang ada yang didorong oleh faktor ekonomi, yaitu pemenuhan kebutuhan hidup; dan ada yang didorong oleh faktor non ekonomi, yaitu lebih untuk pemenuhan keinginan hasrat hawa nafsu. Motif subyektif menggambarkan faktor ekonomi; dan motif obyektif menggambarkan bukan faktor 
ekonomi, melainkan dipengaruhi oleh faktor psikis, sosiologis dan lain-lainnya. Selain itu kedua motif tersebut menggambarkan pula sebuah indikasi moralitas dan etika. Motif subyektif menggambarkan kualitas moral dan etika yang baik, sedang motif obyektif menggambarkan kualitas moral dan etika yang kurang baik. $^{14}$

\section{Tujuan Perilaku Konsumsi Masyarakat}

Kegiatan ekonomi yang pada dasarnya lebih bersifat suatu ikhtiar untuk memenuhi kebutuhan hidup bersama seluruh individu, namun dalam perjalanannya berubah menjadi suatu upaya untuk memperbesar kepemilikan atau persediaan. Karena itu yang menonjol kemudian adalah keserakahan dalam memiliki pesediaan material dan bukan lagi sarana untuk dapat mencukupkan persediaan akan kebutuhan yang ada. Hal ini menurut Machasin, secara makro terlihat jelas dalam pengerukan sumber daya alam secara besar-besaran di satu sisi dan hasil dari pengerukan itu dikonsumsi dengan cara yang sangat tidak hemat di lain sisi. ${ }^{15}$ Sikap hemat dirasakan bertentangan dengan atau dapat menodai harga diri orang yang memiliki persediaan atau harta yang lebih. Semakin besar jumlah harta yang dimiliki seseorang semakin besar pengeluarannya untuk hal-hal yang tidak bermanfaat.

Kegiatan ekonomi saat ini sebagaimana dikatakan Suparlan Suhartono, bahwa ia telah menjadi lahan subur bagi sifat serakah, sikap dan perbuatan bersaing yang bercorak liberalisme kapitalistik, yang mengancam dan merusak moral persamaan dan kerja sama sebagai asas dasar kehidupan sosial manusia, sehingga yang terjadi adalah siapa yang kuat dialah yang menang, sebaliknya mereka yang lemah, yang tidak bermodal tetap sulit keluar dari penderitaan. Kini hampir sebagian besar manusia di

\footnotetext{
${ }^{14}$ Sulistyo, Pengantar Ekonomi ..., h. 124-125.

${ }^{15}$ Machasin, Islam Teologi Aplikatif (Cet. ke-1; Yogyakarta: Pustaka Alief, 2003), h. 160.
} 
dunia ini terjebak dalam suatu krisis moral yang parah. Sistem ekonomi kapitalis dengan orientasi yang materiaslistis sudah hampir menyelimuti dunia ini, sehingga krisis moral tersebut sulit diatasi. Akibatnya lingkungan hidup disekitar kita banyak yang tidak sehat dan sumber dayanya juga dalam krisis, bahkan kini krisis lingkungan hidup telah menjadi isu global. Dunia manusia seolah terbelah menjadi dua, yaitu mereka yang berebut kemewahan dan mereka yang menahan lapar dahaga. Kedua belah pihak inilah yang saling berperang dan mereka bersamasama saling berlomba mengeksploitasi sumber daya alam dan mencemari lingkungan hidup. ${ }^{16}$

Lebih dari itu menurut Suparlan, bahwa kegiatan ekonomi saat ini sebenarnya telah terjadi paradoksal di dalamnya. Di satu sisi (dalam aspek produksi), yaitu yang berhubungan langsung dengan barang-barang dan jasa-jasa produksi memperlihatkan pertumbuhan yang amat signifikan; namun di sisi lain, mengakibatkan pergeseran nilai-nilai yang terkandung dalam pandangan hidup dari yang kualitatif spiritual menjadi kuantitatif material, yang dari padanya menyebabkan semakin menurunnya derajat moralitas kebanyakan orang sebagai manusia. Paradoksal dan pergesaran itu termasuk terjadi dalam mikro ekonomi, yaitu motif perilaku konsumsi seseorang bukan lagi didorong atau dipengaruhi oleh faktor material semata, tetapi juga dipengaruhi oleh faktor manusia atau individu lain. sehingga seseorang dalam berperilaku konsumsi akan merasa selalu dinilai oleh orang lain.

Machasin menambahkan, perilaku konsumsi seseorang tidak hanya bersifat atau bertujuan memenuhi kebutuhan hidupnya semata, tetapi juga untuk memenuhi tuntutan perilaku konsumsi dan penilaian orang-orang lain demi sebuah kepercayaan diri dan martabat kemanusiaan. ${ }^{17}$ Machasin

\footnotetext{
${ }^{16}$ Suparlan Suhartono, Filsafat Ilmu Pengetahuan (Ujung Pandang: Program Pascasarjana Universitas Hasanuddin, 1997), h. 3.

${ }^{17}$ Machasin, Islam ..., h. 161.
} 
mencontohkan, orang yang hanya memiliki sepeda merasa lebih rendah dari pada orang yang memiliki sepeda motor, orang yang naik sepeda motor merasa minder di hadapan orang yang naik mobil. Demikian seterusnya sehingga dapat dikatakan semakin banyak, mahal dan canggih produk-produk material yang dimiliki seseorang, semakin tinggi martabatnya dan semakin tinggi kepercayaan dirinya. ${ }^{18}$

Perilaku konsumsi seseorang-teristimewa pada era modern saat ini-tidaklah selamanya menuruti obyektivitas tingkat kemampuan ekonomi, tetapi menuruti pula perilaku konsumsi dan penilaian subyektivitas orang lain. Perilaku konsumsi seseorang menurut Jean P. Baudrillard, merupakan buah dari komunikasi yang intens dari barang dan jasa konsumsi, perilaku konsumsi dan penilaian orang lain. Dalam perilaku konsumsi seseorang terjadi pemaksaan diri atau tidak terjadi pengindahan fitrah independesi diri. Di satu sisi bermaksud memperlihatkan kemewahan dan kesenangan serta martabat dan kepercayaan diri, di lain sisi terjadi kepalsuan yang tidak mendatangkan ketenangan batin bagi individu pelaku. Akan tetapi memang pada dasarnya manusia yang sekaligus makhluk ekonomi dan makhluk sosial, relatif tidak mungkin sepenuhnya terlepas penuh dari penilaian atau pengaruh dari sesamanya dalam aspek apa pun, termasuk perilaku konsumsi.

Perilaku konsumsi menurut ilmu ekonomi konvensionalyang kapitalistik-bertujuan selain memenuhi tingkat kepuasan maksimal, juga mengejar status sosial dan status ekonomi di tengah-tengah masyarakat. Seorang konsumen ingin agar mendapat pujian dan pengakuan sosial dari seseorang atau publik sebagai seorang yang memiliki status sosial dan stutus ekonomi yang tinggi. Seorang konsumen biasanya menjadi sangat senang

${ }^{18}$ Jean P. Baudrillard, La sociēttē de consommation, diterjemah oleh Wahyunto, Masyarakat Konsumsi (Cet. ke-1; Yogyakarta: Kreasi Wacana, 2004), h. xxxv. 
dan bangga jika perilaku konsumsinya melebihi konsumen lainnya dalam kehidupan keseharian ditengah-tengah masyarakat.

\section{ETIKA KONSUMSI DALAM ISLAM}

Perilaku konsumsi seringkali dipandang sebagai homogenisasi atau heterogenisasi budaya global. Homogenisasi dapat diartikan bahwa budaya lokal akan terkooptasi oleh budaya global atau justru yang terjadi sebaliknya. Budaya lokal akan semakin menunjukkan eksistensinya di tengah berkembangnya budaya global. ${ }^{19}$ Perubahan perilaku konsumsi seringkali dipandang sebagai hal yang negatif, menjadi kambing hitam dalam beberapa hal termasuk terdegradasinya budaya lokal, budaya bangsa maupun budaya Islam.

Sebagaimana dalam ilmu ekonomi konvensional, bahwa motif perilaku konsumsi dikenal dua macam, yaitu motif internal (dari diri manusia) dan motif ekstenal (dari luar diri manusia), demikian juga dalam Islam terdapat apa yang disebut motif internal dan eksternal dalam konsumsi. ${ }^{20}$

\section{Motif Internal}

Adapun motif internal yang dimaksud adalah motif yang tumbuh dalam diri seorang muslim dalam bentuk ingin selalu hidup sehat dan kuat. Motif ini didasarkan pada hadis Nabi saw. berikut ini:

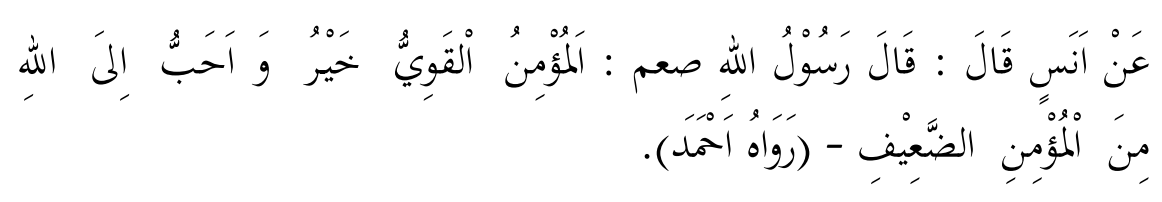

\footnotetext{
${ }^{19}$ AlFitri, "Budaya Konsumerisme Masyarakat Perkotaan" dalam Majalah Empirika, Vol. XI. No. 01, ( 2007), h.1

${ }^{20}$ M. Nasri Hamang Najed, Ekonomi Islam; Zakat Ajaran Kesejahteraan dan Keselamatan Umat: Pokok-pokok Fiqhiyyah, Landasan Perekonomian, Sejarah dan Manajemen Zakat (Parepare: LbH Press, 2013), h. 39-43.
} 
Dari Anas, ia berkata, Rasulullah saw. bersabda: Orang mukmin yang kuat lebih baik dan lebih disukai Allah dari pada orang mukmin yang lemah (H. R. Ahmad).

\section{Motif Eksternal}

Sedangkan motif eksternal yang dimaksud adalah sebuah motif dari luar diri manusia dalam bentuk ingin memenuhi kebutuhan kenyamanan dari pelakunya dan secara sosiologis ingin mendapatkan penilaian positif (visualitas estetik) dari orang lain atau publik. Motif ini merupakan motif yang secara syar'i termasuk absah dan positif. Motif ini didasarkan pada hadis Nabi saw. berikut:

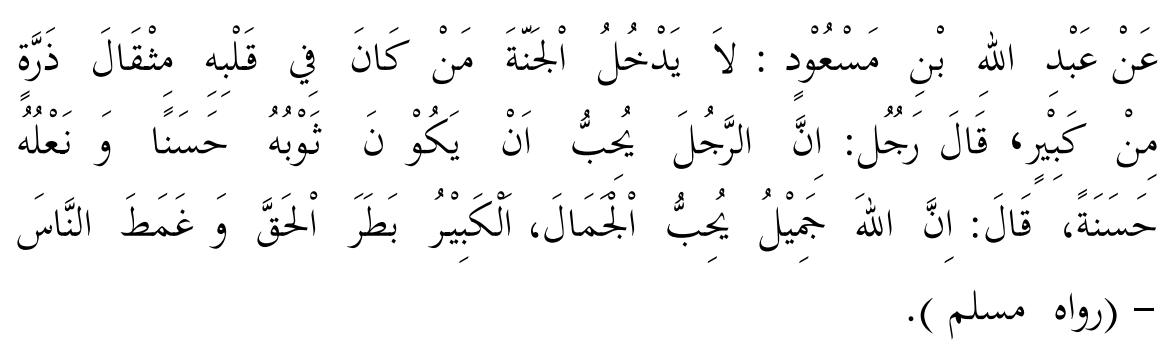

Dari Abdullah bin Mas'ud, ia berkata, Rasulullah saw. bersabda: tidak akan masuk surga orang yang di dalam hatinya terdapat kesombongan walau hanya sekecil atom (dzarrah). Seorang laki-laki berkata: bahwa sesungguhnya bagaimana halnya seorang laki-laki yang memakai baju dan sepatu/sandal yang bagus. Rasulullah berkata: bahwa sesungguhnya Allah itu indah dan menyukai yang indah. Kesombongan itu mengenyahkan kebenaran dan merendahkan manusia - (H.R. Muslim).

Seperti dirasakan dan disaksikan dalam kehidupan seharihari, bahwa hidup sehat dan kuat mutlak harus ditopang oleh perilaku konsumsi, baik perilaku konsumsi yang berkaitan sandang maupun pangan ataupun papan. Bahkan perilaku konsumsi itu telah diatur dalam Islam sedemikian rupa guna mencapai tingkat kesehatan dan kekuatan yang prima. Demikian juga halnya kehidupan yang ditopang oleh fasilitas yang baik atau bagus, akan mendatangkan perilaku hidup yang baik dan bagus pula, baik perilaku itu bersifat perilaku keagamaan maupun bersifat perilaku keduniaan. 
Dalam pandangan Islam, perilaku konsumsi mempunyai tujuan yang berbeda dengan tujuan perilaku konsumsi dalam pandangan ekonomi konvensional (yang materialistik) yang hanya ingin memenuhi kebutuhan jasmaniah lahiriah, melainkan di samping memenuhi kebutuhan jasmaniah lahiriah, juga memenuhi kebutuhan rohaniah batiniah.

Hal ini dapat diuraikan dalam tujuan-tujuan konsumsi dalam pandangan Islam sebagai berikut:

\section{Tujuan Materil}

Adapun tujuan materil dari perilaku konsumsi dalam pandangan Islam dapat dipahami dari ayat dan hadis berikut:

- Mendatangkan Kesehatan Fisik. Dalam Q.S. al-A'rāf (7): 31 dipaparkan:

Hai anak Adam, pakailah pakaianmu yang indah di setiap (memasuki) masjid, makan dan minumlah, dan janganlah berlebih-lebihan. Sesungguhnya Allah tidak menyukai orang-orang yang berlebihlebihan.

- Menjaga dan Menutup Aurat. Sebagaimana ditegaskan dalam Q.S. al-A'rāf (7): 26 dan 32:

Hai anak Adam, Sesungguhnya kami telah menurunkan kepadamu pakaian untuk menutup auratmu dan pakaian indah untuk perhiasan. dan pakaian takwa itulah yang paling baik. yang demikian itu adalah sebahagian dari tanda-tanda kekuasaan Allah, mudah-mudahan mereka selalu ingat.

Katakanlah: "Siapakah yang mengharamkan perhiasan dari Allah yang telah dikeluarkan-Nya untuk hamba-hamba-Nya dan (siapa pulakah yang mengharamkan) rezki yang baik?" Katakanlah: "Semuanya itu (disediakan) bagi orang-orang yang beriman dalam kehidupan dunia, khusus (untuk mereka saja) di hari kiamat." Demikianlah kami menjelaskan ayat-ayat itu bagi orang-orang yang mengetahui.

- Memberikan Kenyamanan Hidup. Rasulullah saw. bersabda:

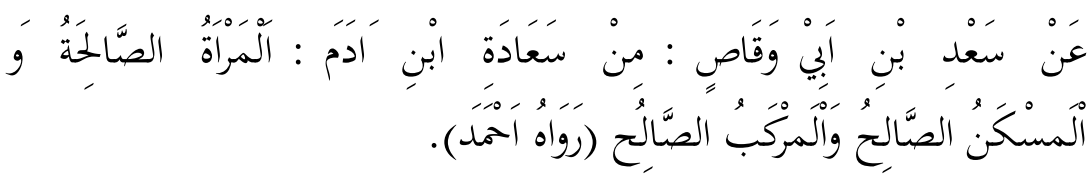


Dari Sa'ad bin Abi Waqqash, ia berkata, Rasulullah saw. bersabda: ada tiga hal yang membahagiakan manusia, yaitu (1) isteri yang salehah, (2) rumah yang bagus dan (3) kendaraan yang bagus (H. R. Ahmad).

\section{Tujuan Spiritual}

Adapun tujuan spiritual dari perilaku konsumsi dalam pandangan Islam antara lain sebagai berikut: pertama, Pembentukan jiwa syukur akan karunia Allah. Dalam pandangan seorang konsumen muslim (hamba Allah), setiap perilaku konsumsi sesungguhnya merupakan realisasi rasa syukur kepada Allah. Hal itu karena tiga faktor; pertama, dikaruniakan-Nya kemampuan untuk mencari bahan konsumsi seperti makanan; kedua, dikaruniakan-Nya bahan konsumsi yang melimpah; dan ketiga, energi yang didapat sesudah menkonsumsi berbagai bahan makanan, semata-mata dipergunakan untuk mempertebal rasa kesyukurannya kepada Allah. Bahwa seorang konsumen muslim dalam setiap perilaku konsumsinya harus teresap dalam dirinya nilai-nilai syukur.

Kedua, pembentukan ahli ibadah yang bersyukur. Seorang konsumen muslim yang telah mengonsumsi berbagai barang konsumsi sekaligus mampu merasakannya sebagai nikmat karunia Allah, akan berkontribusi besar dalam mengaksesnya untuk senantiasa menunaikan ibadah dengan berlandaskan atas syukur akan nikmat karunia Allah. Ibadah yang dilakukan berulang-ulang dengan berdasarkan atas rasa syukur akan nikmat karunia Allah, secara otomatis akan membentuk pelakunya menjadi ahli ibadah dengan tingkat kualitas pengamalan ibadah yang paling tinggi nilainya di mata Allah. Allah mengisyaratkan, bahwa dalam melakukan ibadah-ibadah kepadanya, hendaknya didasarkan atas rasa syukur akan nikmat karunia-Nya. Hal ini ditegaskan Allah dalam Q.S. al-Baqarah (2):172.

Hai orang-orang yang beriman, makanlah di antara rezki yang baik-baik yang kami berikan kepadamu dan bersyukurlah kepada Allah, jika benar-benar kepada-Nya kamu menyembah. 


\section{PERILAKU KONSUMSI DALAM PANDANGAN EKONOMI ISLAM}

Islam sebagai pedoman hidup mengatur segenap perilaku manusia dalam memenuhi kebutuhan hidupnya. Demikian pula masalah konsumsi, Islam mengatur bagaimana manusia bisa melakukan kegiatan-kegiatan konsumsi yang membawa manusia berguna bagi kemaslahatan hidupnya. Islam telah mengatur jalan hidup manusia melalui Alquran dan Hadis, supaya manusia di jauhkan dari sifat yang hina karena perilaku konsumsinya. Perilaku konsumsi yang sesuai dengan ketentuan Allah dan Rasulullah saw. akan menjamin kehidupan manusia yang lebih sejahtera. $^{21}$

Seorang muslim dalam berkonsumsi didasarkan atas beberapa pertimbangan: pertama, Manusia tidak kuasa sepenuhnya mengatur detail permasalahan ekonomi masyarakat atau Negara, bahkan manusia tidak dapat memaksakan cara pemenuhan hidup orang lain kepada dirinya ataupun sebaliknya. ${ }^{22}$ Terselenggaranya keberlangsungan hidup manusia diatur oleh Allah swt. dalam Q.S. al-Waqi'ah (56): 68-69.

Maka Terangkanlah kepadaku tentang air yang kamu minum. Kamukah yang menurunkannya atau kamikah yang menurunkannya?

Kedua, dalam konsep Islam kebutuhan yang membentuk pola konsumsi seorang muslim, sebab pola konsumsi yang didasarkan atas kebutuhan akan menghindari pengaruhpengaruh pola konsumsi yang tidak perlu. Dalam Q.S. Āli 'Imrān (3):180 dijelaskan:

\footnotetext{
${ }^{21}$ Heri Sudarsono, Konsep Ekonomi Islam; Suatu Pengantar (Yogyakarta: Ekonisia, 2002), h. 151.

${ }^{22} \mathrm{Al}-\mathrm{Gh} a z a l i$ menegaskan, pasar terbentuk secara alami yang ditimbulkan oleh adanya perbedaan kebutuhan satu orang dengan orang lain. Sedangkan Adam Smith memetaforakan keberadaan kekuatan-kekuatan tertentu yang mendorong manusia untuk saling berhubungan dalam memenuhi kebutuhannya dengan istilah invisible hand (tangan gaib). Heri Sudarsono, Ibid.
} 
Sekali-kali janganlah orang-orang yang bakhil dengan harta yang Allah berikan kepada mereka dari karunia-Nya menyangka, bahwa kebakhilan itu baik bagi mereka. Sebenarnya kebakhilan itu adalah buruk bagi mereka. harta yang mereka bakhilkan itu akan dikalungkan kelak di lehernya di hari kiamat. dan kepunyaan Allah-lah segala warisan (yang ada) di langit dan di bumi. dan Allah mengetahui apa yang kamu kerjakan.

Ketiga, Perilaku konsumsi dalam pandangan Islam akan melihat bagaimana suasana psikologi orang lain. Dengan konsep ini maka Islam menjamin terbangunnya pembangunan masyarakat yang berkeadilan, terhindar dari kesenjangan sosial atau diskriminasi sosial. Q.S. al-Nisā (4): 29 menjelaskan:

Hai orang-orang yang beriman, janganlah kamu saling memakan harta sesamamu dengan jalan yang batil, kecuali dengan jalan perniagaan yang berlaku dengan suka sama-suka di antara kamu. dan janganlah kamu membunuh dirimu; Sesungguhnya Allah adalah maha penyayang kepadamu.

Teori ekonomi menjelaskan bahwa kepuasan seseorang dalam mengkonsumsi suatu barang dinamakan utility atau nilai guna. Jika kepuasan semakin tinggi maka semakin tinggi pula nilai gunanya, sebaliknya bila kepuasan semakin rendah maka semakin rendah pula nilai gunanya. Oleh karena itu kepuasan seorang muslim tidak didasarkan atas banyak sedikitnya barang yang bisa dikonsumsi, tetapi lebih dikarenakan apa yang dilakukannya sebagai ibadah dengan memenuhi apa yang diperintahkan Allah swt dan menjauhi segala larangan Allah swt. Tindakan-tindakan yang merugikan, seperti pemborosan, dilarang Allah sebagaimana tersebut dalam Q.S. al-Israa' (17): 2627.

Dan berikanlah kepada keluarga-keluarga yang dekat akan haknya, kepada orang miskin dan orang yang dalam perjalanan dan janganlah kamu menghambur-hamburkan (hartamu) secara boros. Sesungguhnya pemboros-pemboros itu adalah Saudara-saudara syaitan dan syaitan itu adalah sangat ingkar kepada Tuhannya. Demikian pula dalam surat alA`raaf/7: 31. Hai anak Adam, pakailah pakaianmu yang indah di setiap (memasuki) mesjid, makan dan minumlah, dan janganlah berlebihlebihan. Sesungguhnya Allah tidak menyukai orang-orang yang berlebih-lebihan. 
Allah swt. menganjurkan hidup dalam keseimbangan sebagaimana tersebut dalam Q.S. al-Furqān (25): 67.

Dan orang-orang yang apabila membelanjakan (harta), mereka tidak berlebihan, dan tidak (pula) kikir, dan adalah (pembelanjaan itu) di tengah-tengah antara yang demikian.

Dari uraian diatas dinyatakan bahwa memperturutkan kepuasan "yang tidak terbatas" akan merusak diri, bukan berarti seorang muslim tidak boleh mendapatkan kepuasan dari konsumsinya terhadap sejumlah barang, tetapi kepuasan seorang muslim dibatasi.

Untuk lebih mejelaskan kepuasan seorang muslim dapat diilustrasikan dalam bentuk nilai guna total (total utility) dan nilai guna marginal (marginal utility). Nilai guna total adalah jumlah seluruh kepuasan yang diperoleh dalam mengkonsumsi sejumlah pertambahan atau pengurangan kepuasan sebagai akibat dari pertambahan atau pengurangan penggunaan satu unit barang. ${ }^{23}$

Dengan demikian kepuasan bukan didasarkan atas banyaknya barang yang dikonsumsi, tetapi didasarkan atas kemampuan fisik manusia dalam menggunakan barang yang dikonsumsinya dalam melangsungkan hidupnya. Sehingga dengan mengurangi konsumsi sebelum mencapai kepuasan maksimal sebagai upaya untuk menjaga konsistensi kepuasan yang diterima seorang muslim dari mengkonsumsi suatu barang, karena tambahan nilai guna yang akan diperoleh akan menjadi semakin sedikit apabila ia terus-menerus menambah konsumsinya, yang demikian dikenal dengan istilah hukum nilai guna marginal yang semakin menurun (the law diminishing return), yang pada akhirnya tambahan nilai guna akan menjadi negative, apabila konsumsi ke atas barang tersebut ditambah terus, maka nilai guna total akan menjadi semakin sedikit.

${ }^{23}$ Ibid., h. 153 
Jika hukum nilai guna marginal semakin menurun maka pertambahan yang terus menerus dalam berkonsumsi suatu barang tidak akan menambah kepuasan dalam berkonsumsi, tetapi lama-kelamaan tingkat kepuasan atas barang semakin menurun. Misalnya seorang berbuka puasa dengan segelas kolak akan mendapat kepuasan, kepuasan akan bertambah bila ditambah satu gelas yang kedua dan sampai gelas ketiga. Kalau ditawarkan gelas keempat, orang tersebut akan menolak karena sudah merasa puas. Orang tersebut menolak karena sudah merasa lebih puas minum tiga gelas kolak dari pada minum empat gelas. Hal ini bermakna nilai guna total dari meminum empat gelas adalah lebih rendah dari nilai guna yang diperoleh dari meminum tiga gelas.

Dengan demikian sebagai upaya dalam mendapatkan kepuasan dalam konsumsi dari setiap barang, seyogyanya setiap muslim akan berusaha memaksimumkan nilai guna dari tiap barang yang di konsumsi dalam memenuhi kebutuhan hidupnya.

\section{PENUTUP}

Dari uraian pembahasan diatas penulis dapat menarik kesimpulan sebagai berikut: Pertama, perilaku konsumsi semestinya dapat memperhatikan aspek-aspek yang tergolong kebutuhan primer (dharuriyat) kemudian sekunder (hajjiyat) dan trisier (tahsiniyat) sesuai dengan semangat al-maqashid asysyariah, sehingga dalam memenuhi kebutuhan seorang konsumen lebih mengedepankan aspek kebutuhan daripada aspek keingingan demi membatasi kebutuhan dan kengingan manusia yang sifatnya senantiasa tidak terbatas.

Kedua, dalam pandangan Islam perilaku konsumsi harus menghindari perilaku isräf dan tabżīr dalam menggunakan pendapatan untuk memenuhi kebutuhan hidup, sebagai ramburambu dalam konsumsi pangan semestinya manusia secara umum dan muslim secara khusus untuk senantiasa menjaga unsur ke- 
halāl-an dan ke-țayyiban-an dalam konsumsi sebagai langkah untuk menjaga kesehatan jasmani dan rohani.

Ketiga, perilaku konsumsi dalam ekonomi Islam bertujuan untuk tercapainya aspek materil dan aspek spiritual dalam konsumsi, kedua aspek tersebut akan tercapai dengan menyeimbangkan antara nilai guna total (total utility) dan nilai guna marginal (marginal utility) dalam konsumsi. Sehingga setiap muslim akan berusaha memaksimumkan nilai guna dari tiap barang yang di konsumsi, yang akan menjadikan dirinya semakin baik dan semakin optimis dalam menjalani hidup dan kehidupan.

\section{DAFTAR PUSTAKA}

AlFitri, "Budaya Konsumerisme Masyarakat Perkotaan" dalam Majalah Empirika, Vol. XI. No. 01, ( 2007).

Ardhanari, Margaretha, Memelihara Budaya: Perspektif Masyarakat Konsumen dan Perilakunya, makalah orasi ilmiah dalam rangka Dies Natalis Universitas Katolik Widya Mandala Surabaya ke-53 tahun 2014, h. 2.

Baudrillard, Jean P., La sociēttē de consommation, diterjemah oleh Wahyunto, Masyarakat Konsumsi, Cet. ke-1; Yogyakarta: Kreasi Wacana, 2004.

Kementerian Agama, Al-Qur'an al-Karim dan Terjemahnya. Bandung: PT. Sygma Examedia Arkanleema, 2010.

Lipsey, Richard. G., Steiner, O. Peter dan Purvis D. Douglas, Economics, diterjemah oleh Jaka Wasana dan Kirbandoko dengan judul, Pengantar Mikroekonomi, Jilid I, Edisi VIII; Jakarta: Erlangga, 1987.

Machasin, Islam Teologi Aplikatif, Cet. ke-1; Yogyakarta: Pustaka Alief, 2003.

Mufraini, M. Arif, Akuntansi dan Manajemen ZakatMengomunikasikan Kesadaran dan Membangun Jaringan, Cet. ke-1 ; Jakarta: Kencana Prenada Media Group, 2006 
Najed, M. Nasri Hamang, Ekonomi Islam; Zakat Ajaran Kesejahteraan dan Keselamatan Umat: Pokok-pokok Fiqhiyyah, Landasan Perekonomian, Sejarah dan Manajemen Zakat, Parepare: LbH Press, 2013.

Qardhawi, Yusuf, Dawr al-Qiyam wa al-Akhlāq fī al-Iqtiṣad alIslāmī, diterjemah oleh Zainal Arifin dan Dahlia Husim, Norma dan Etika Ekonomi Islam, Cet. ke-4; Jakarta: Gema Insani Press, 1422 H./2001 M.

Salvatore, Dominick, Theory and Problems of Microeconomics, diterjemah oleh Rudy Sitompul, Teori Mikroekonomi, Cet. ke-3; Jakarta: Erlangga, 1995.

Siddiqi, Muhammad Nejatullah, The Economic Enterprise, diterjemah oleh Anas Sidik, Kegiatan Ekonomi dalam Islam, Cet. ke-2; Jakarta: Bumi Aksara, 1996

Sudarsono, Heri, Konsep Ekonomi Islam; Suatu Pengantar, Yogyakarta: Ekonisia, 2002.

Suhartono, Suparlan, Filsafat Ilmu Pengetahuan, Ujung Pandang: Program Pascasarjana Universitas Hasanuddin, 1997.

Sulistyo, Pengantar Ekonomi Makro, Cet. ke-3; Jakarta: Karunika Universitas Terbuka, 1986

Syāṭib̄i, Abu Ishaq al-, al-Muwāfaqāt Fī Ușūl al-Syarīah, Juz IV, Beirut: Dār al-Kutub al-'Ilmiyyah,; t.th.

Winardi, Manajemen Perilaku Organisasi, Cet. ke-1; Bandung: Mandar Maju, 2003. 